\title{
GOOD GOVERNANCE AND TRANSPARENCY
}

\author{
BUENA GOBERNANZA Y TRANSPARENCIA
}

\section{Laura Vilone}

Université Paris-Nanterre, France

\begin{abstract}
The notion of "good governance" implies the special place given to the State. Such a model is defined by the effectiveness of certain guarantees such as the independence of the judiciary, the correct and fair management of expenditure but also administrative transparency. Indeed, the latter depends on the sincerity of those involved in public action, on the one hand, and the constant dialogue between the public authorities and the public, on the other hand. The purpose of this intervention is to demonstrate that the realisation of the model of "good governance" is based, above all, on the existence of an administration that fully understands the requirements of administrative transparency. The two pillars of "good governance" would thus be the foundations of the principle of transparency: communication with citizens and their participation in the process of the decision-making process.
\end{abstract}

Keywords: Good governance, administrative transparency, participation, public law.

\section{Resumen}

La noción de «buena gobernanza» implica el lugar especial que se le otorga al Estado. Tal modelo se define por la efectividad de ciertas garantías como la independencia del poder judicial, la correcta y justa gestión del gasto, pero también la transparencia administrativa. En efecto, lo último depende de la 
sinceridad de los involucrados en la acción pública, por un lado, y del diálogo constante entre las autoridades públicas y el público, por otro. El propósito de esta intervención es demostrar que la realización del modelo del "buen gobierno" se basa, sobre todo, en la existencia de una administración que comprenda plenamente los requisitos de la transparencia administrativa. Los dos pilares del «buen gobierno» serían, por tanto, los pilares del principio de transparencia: la comunicación con los ciudadanos y la participación de estos en el proceso de toma de decisiones.

Palabras clave: buen gobierno, transparencia administrativa, participación, derecho público.

\section{Introduction}

As a reminder: the word 'governance' was coined for the first time in the World Bank's 1992 speech. It was defined as "the manner in which every country exercises its power in the management of economic and social resources". The resulting concerns are: establishing politics that are predictable and transparent; creating a model of an executive body that is accountable and works with private companies; those private companies participate in public affairs and above all, a model where everyone behave as per the law.

Therefore, the notion of 'governance' necessarily implies the special place given to the State. We are witnessing a shift from the notion of 'government' to the notion of 'governance'. The latter has gotten rid of the authoritarian aspect associated to the former, which means "action or manner of leading or governing".

The expression 'good governance' originates by associating the governance with some guarantees including the independence of the judiciary, a correct and fair management of the expenditure, managers who report their actions but also administrative transparency.

The notion of 'transparency' is particularly difficult to understand. Our article lays on the elements that define transparency within the French system. In any event, we must clearly distinguish between our leaders' transparency and the openness of the administrative activities, which applies to the relation between the public administrations and the citizens. The last one is about sharing the various stages of administrative actions with people. 
Does the model of good governance depend on the effective application of a transparency principle?

First, the concern to apply the principle of transparency led to a redefinition of the position of the State apparatus towards citizens. It means that public administration is now expected to inform them and do the decision-making process readable. Then, it modified its role: the State is now an actor, just as citizens (individuals or legal entities). These are, therefore the two approaches to administrative transparency that fully correspond to the definition of good governance: communication by administration (2) and citizen participation (3).

This article proposes the answer to the following question: how does the model of good governance lean on the notion of administrative transparency?

\section{2. 'Good governance' by informing the citizens}

'Good governance' leans on two very important actions and principles: by providing access to the authorities' decisions regarding the activity of public services (2.1) but also by ensuring the sincerity of the government (2.2).

\subsection{The access to administrative documents}

The first step towards transparency is "communication to citizens". It is initially understood in a broad sense. It can be in three forms: the communication of one document, a general communication concerning political actions, and the communication with officials.

The first one corresponds to the progress achieved by three laws of 1978, especially the consecration of the right of access to administrative documents and the creation of the Access Commission for Administrative Documents. It is by this consecration that administrative transparency finally acquired, for the first time, a law dimension and became a part of substantive law.

Since 2016, this right has been codified. The rules applying are now in the Code des Relations entre le Public et l'Administration. Article L. 311-1 states that "subject to the articles L. 311-5 and L. 311-6, the administrations mentioned in article L. 300-2 are required to publish online or communicate the administrative documents they hold to the person who requests them, under the conditions laid down in the first book". The main exceptions are, for example, 
opinions of the Council of State or administrative courts, administrative documents whose communication would undermine the secrecy of government and responsible authorities of the executive branch deliberations, the secrecy of national defence, the conduct of French foreign affairs, State security, public safety, personal safety or the security of government informational system, currency and public credit, the conduct of proceedings before the court, the investigation and prevention of offensive (Article L. 311-5). Some documents are also only available for the people concerned, for example, the disclosure of which could violate privacy, medical confidentiality, and business secrecy (Article L. 311-6).

The president of the Access Commission for Administrative Documents made a positive assessment of the application of the new legislation and in particular Act n. 2016-1321 of October 7, 2016, for a digital Republic. The main innovation of this law is the introduction of Open Data by Default, which means the obligation for public authorities to publish online the majority of their documents. Previously, many public authorities had already practiced open data, but it was their choice. ${ }^{1}$ This progress also represents the main difficulty, as its implementation remains rather slow. There is still some caution from the administration regarding which secret must be protected. A "guide to good practice" is missing, a guide the Commission has not been able to write until now.

In addition to the activities of the commission, we also notice a constant effort the dematerialize administrative documents of soft law such as notices and reports to inform the public about administrative activities. For example, the National Commission for the Control of Intelligence Techniques published its third activity report on the effectiveness of internal security code providing that the intelligent services may be authorized to provide techniques for gathering information. Another example is a document from the Government to the Parliament regarding the enforcement of the strengthening internal security law and the anti-terrorism law of October, 30, 2017.

1 Marc Dandelot, "Évolution et enjeux du droit d'accès aux documents administratifs depuis la loi du 7 octobre 2016 pour une République numérique", Revue française d'administration publique $165, \mathrm{n}^{\circ} 1$ (2018): 127-133. 


\subsection{Transparency of public actors}

Informing the public also implies a complete trust in the public authorities, who are the administrative decision-makers. The issue of the transparency of leaders is at the heart of political and sociological debates, especially since the creation of the High Authority of Transparency in Public Life in 2013. This agency controls 15,800 public officials and ensures that they comply with their obligations to declare their assets and liabilities.

Practically speaking, they have to file a declaration aiming "at providing precise photography of the assets and interests held by a public official at a given time. Filing guidelines published by the High Authority detail practical modalities, delays to file declarations, the exact content of each field of the declarations, the modalities - if applicable - of the publication of these declarations, how they should signal any evolution in their assets or interests or how to obtain support for filling the declaration"2.

A year earlier the Commission of Administrative Ethics was created and has delivered its first opinions in 2012. This Commission is composed of two elected members (one member of the Council of State and one of the Administrative Courts of Appeal), and a member appointed by the vice-president of the French Council of State for a renewable three-year term. Its creation stems from the desire to ensure the uniform application of the deontology code for the administrative courts' members.

In a recent case, the Commission had the opportunity to rule on the compatibility between the exercise of jurisdictional functions and the ministerial activities. The case concerned the wife of a former Home Affairs Secretary. She had already been the subject of an opinion by the Ethics Committee when she was assigned to exercise jurisdictional functions at the Parisian Administrative Court of Appeal. The Committee established that she could continue her jurisdictional activity, and provided that she doesn't take any case concerning the Ministry, including, of course, affairs regarding foreign nationals and refugees. Last year, a new request concerning her choice to the position of President of the Agency of Territorial Referents of a political party (La République en Marche) for the Rhône district. This time, the Committee decided that an administrative magistrate can assume a position of responsibility within a po-

2 https://www.hatvp.fr/en/high-authority/ethics-of-publics-officials/list/\#what-to-declare-rp 
litical party on the twofold condition: first, the obligations inherent to this responsibility do not affect his availability to exercise the judicial functions; and second, this position led to express oneself in a way that will not be compatible with the obligation of the reserve (Opinion n. 2018-1, February 7, 2018).

This dialog also expresses itself from a jurisdictional point of view. Indeed, if the leaders are accountable to the public, the Council of State has considered that they can. In return, contest the documents that expose them. In its ruling of July 19, 2019, the Council of State considered that "the appraisal that the High Authority of Transparency in Public Life thinks that the declaration of their patrimonial situation has to include an assessment from the authority is justified by completeness, accuracy and sincerity imperatives that is incumbent on the author of this declaration. Even though it has no legal effects, this position of an administrative authority which is published with the declaration of assets based on LO 135-2 from the Electoral Code, produces important effects on the person who is the subject of the declaration, in terms of reputation, particularly. These effects can affect people's behaviour, especially voters, who read this assessment. So, from this standpoint should be an act which produces effects on the subject of the declaration. It follows that the applicant is entitled to request the annulment of October 24, 2018 decision, related to her declaration of assets and liabilities".

According to the Public Ethics Observatory, the last amendments are more focused on the parliament openness, putting aside the official's transparency. Indeed, the attention should be not only on the officials but also on high members of public service. "Law hardly penetrate the fortress of the Elysée equally regarding their collaborators' legal statute, compatibility, public procurement or access to administrative documents". For the officials, too many secretive elements remain concerning officials' life such as ministers' representation expenses and the work of the Ministerial Cabinet.

This concern responds to a double rationale: first, about control, but also about warning and advice. Such approaches are preferred for disciplinary measures. We chose a model of dialog with the officials, and this choice is more compatible with good governance. 


\section{3. 'Good governance' by rebalancing the relationship between administrative authorities and citizens}

Such a model only is achievable by going beyond communication. Law now contains participation procedures so the citizens can participate in the decision-making process (3.1). This leads to a change in the role of the State in society (3.2).

\subsection{The citizens' involvement in the decision-making process}

Gradually, the right to the information mentioned above has been linked to procedures for direct consultation to the citizens. It means that citizens are asked to give their general opinion on a new policy, the organisation of public services, and also about a more specific point. For example, they can give their opinion regarding a local decision (in the city they live in).

For the first way of participation, the mechanisms are quite old. However, the second way concerns what is called 'local democracy'. The citizens benefit from local means to express their point of view. The aim is to ensure the continuity of the circuit going from the citizen to the central administration.

Participation goes far beyond communication since it amounts to a kind of upstream control of administrative action by the public. Whereas communication only allows observing, participation allows communicating an opinion before a decision is made. Part of the legal doctrine considers that public participation surpasses administrative transparency and associates it with the concept of "administrative democracy".

This statement leads us to this conclusion: we understand that transparency, by itself, cannot engender the model of good Governance without associating it with a principle of participation. This participation principle should be nearly self-controlling.

The Code des Relations entre le Public et l'Administration provides various participation mechanisms. When it is required to consult a consultative commission before issuing a regulatory act, Article L. 132-1 gives the Administration the option of organising an open consultation which replaces the compulsory consultation pursuant to a legislative or regulatory provision. The decision to organise that consultation shall be published online and the Administration shall precise the terms of this consultation. A summary of these observations is established and published online (Article L. 132-1 and following of the Code). 
However, this is not the only form of participation provided by the Code. Article L. 134-2 provides setting up a public inquiry to ensure the information, the citizens' participation, and the inclusion of their opinion during the decision-making process. Observations and proposals gathered during the investigation are taken into consideration by the competent administration before the decision-making.

Besides, the deliberative assembly of a local authority can organise a local referendum about any project of a decision falling within this local administration competence (Article L. 135-1 of the Code).

Public consultations become more and more frequent. For example, the Code's provisions we mentioned were used at the time of the codification of the rules applicable to public procurement. In light of this, a public consultation was opened on the website of the Ministry of the Economy from April 2018 until the end of May 2018. Concretely, to participate in this consultation, citizens had to fill a pre-established table. In the end, a summary of the different observations was published online.

The Constitutional Amendment of 2008 and the Organic Law of 2010 opened up the possibility for citizens to submit a petition to the Economic, Social and Environmental Council [EESC] concerning a matter of general economic, social and environmental interest. This is a wide-ranging initiative. At least 500,000 people must sign the petition. The board statute on the admissibility of the petition before the EESC delivers an opinion to the Plenary Assembly within one year. The opinion is forwarded to the Prime Minister, the President of the National Assembly and the President of the Senate and petition's representative. The document is published at the official journal. Only two petitions, initiated by citizens, were brought before the Council so far.

At this point, we could make the following observation: some participation procedures for the citizens are wide extent procedures; others are more close initiatives such as participating in the decision-making process of a local decision. For the second one - as we established before- the citizen becomes one of the decision-makers. Citizens' voices are less heard in the first attempt than in the second type of mechanism. We would wonder: could the first mechanisms, as they are set with such conditions of admissibility, correspond to the model of good governance? On the contrary, it seems that only the spontaneous and local participation initiatives, individual and systematic, are compatible with the system of good governance and can improve it. Only those initiatives, indeed, can create a truthful and constant dialog with admi- 
nistrative authorities and the government. Large-scale mechanisms just slow down administrative activity.

\subsection{A State coexisting with its citizens}

The argument shows that the expression 'good governance' is associated with many concepts and is rooted in a model of administrative transparency. The true valid point is the profound evolution of the role of the State. In the seventies, came the right of access to official documents and the end of administrative secrecy. The aim has been to establish an egalitarian relationship between the administration and its public. The role of public authorities remain unchanged, but they were now accountable.

Today, this progress seems to have been achieved. The 'good governance' model reflects a different ambition: the ambition of a State which does not only implements sovereign activities. The State is no longer an economic or social actor. We are no longer talking about equality but rather about the duty of Administration in favour of the citizen. The system spotlights private actors. To quote Jacques Chevallier, a very important figure of French administrative science, it's the "irreversible decline of national sovereignty", " an integrated world in which States are more regulated than regulators and are caught in the meshes of a game whose control is now beyond their gasp" ${ }^{\prime 4}$. We are very far from the 'policing' state.

Thus, to pursue the model we described in our Introduction, the solution seems simple: generalize open data and multiply the mechanisms of citizen participation.

Real progress has been accomplished even in sensitive subjects such as environmental law. Indeed, public consultation in these matters is discussed by the doctrine. This debate is the result of a reform initiated in the eighties. Act n. 2016-1060 of August 3, 2016, ratified by the Act 2018-148 of March 2, 2018, set a change regarding the participation of the public for the decisions which could have a significant impact on the environment ${ }^{5}$. Initially, only one public

3 Jacques Chevallier, "La gouvernance, un nouveau paradigme étatique", Revue française d'administration publique 105-106, $\mathrm{n}^{\circ} 1$ (2003): 203-217.

4 Chevallier, "La gouvernance, un nouveau paradigme étatique ?", 203-217.

5 Jean-François Struillou, "La participation du public en matière d'environnement: le changement dans la continuité", L'Actualité juridique. Droit administratif 24 (2018): 1392. AJDA 2018, p. 1392. 
inquiry was provided for, but this came too late and did not allow inhabitants to express their views. A text related to local democracy (the literal translation: "proximity democracy") in 2002 included a procedure of public debate. This time, the public debate was supposed to intervene upstream and Article L. 103-2 of the Town Planning Code also provided a consultation procedure requiring the Administration to consult inhabitants, local associations, and people concerned, all along the process of decision-making.

Lastly, the 2010 Grenelle II Act introduces a procedure of "initial consultation before the public inquiry" that may be organised by the person responsible for the project when this project is not subject to the provisions of the Town Planning Code.

However, this procedure remains optional and depends entirely on the will of the public person responsible for the project, which remains unsatisfactory.

The 2016 amendment has made it possible to generalise the use of consultation before the public inquiry. A citizens' right of initiative has been instituted, giving them the possibility of requesting the prefect to set up a consultation procedure if this has not been done.

By combining those two pillars that would lead to a transparent administrative system, we come to what was defined as good governance in the Introduction. Thus, it seems that one can only speak of good governance once this model of administrative transparency has been joined. Administrative transparency would, therefore, precede the model of good governance, which would be more a result of the existence of these guarantees and not a model that creates them. 


\section{REFERENCES}

Chevallier, Jacques. "La gouvernance, un nouveau paradigme étatique?". Revue française d'administration publique 105-106, n. ${ }^{\circ} 1$ (2003): 203-217.

Dandelot, Marc. "Évolution et enjeux du droit d'accès aux documents administratifs depuis la loi du 7 octobre 2016 pour une République numérique". Revue française d'administration publique 165, n. $^{\circ} 1$ (2018): 127-133.

Struillou, Jean-François. "La participation du public en matière d'environnement: le changement dans la continuité", L'Actualité juridique. Droit administratif 24 (2018): 1392.

\section{About the author}

Ph. D. candidate in Public Law from the Paris Nanterre University, thesis: The Codification of Administrative Law in France and Italy. Master in French Law, in Italian Law, and in Public Law. Since 2017 is a Teaching Assistant in Administrative Law (University of Vincennes in Saint-Denis), besides a Legal Assistant at the First Chambre of the French Council of State. 